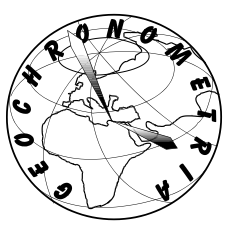

\title{
MESOPLEISTOCENE LOESS DEPOSITS IN THE MAMALYHA 2 PROFILE OF UKRAINE - INTERLABORATORY COMPARISON OF THE THERMOLUMINESCENCE DATING RESULTS
}

\author{
MARIA LANCZONT ${ }^{1}$, ANDRIJ B. BOGUCKI ${ }^{2}$, STANISŁAW FEDOROWICZ ${ }^{3}$ \\ and JAROSŁAW KUSIAK ${ }^{1}$ \\ ${ }^{I}$ Department of Physical Geography and Palaeogeography, Maria Curie-Skłodowska University, \\ Al. Kraśnicka 2 cd, 20-718 Lublin, Poland \\ ${ }^{2}$ Department of Geomorphology and Palaeogeography, Ivan Franko National University, \\ Doroshenka 41, 79000 Lviv, Ukraine \\ ${ }^{3}$ Department of Geomorphology and Quaternary Geology, University of Gdańsk, \\ Bażyńskiego 4, 80-950 Gdańsk, Poland
}

Received 1 October $2010 \quad$ Accepted 25 March 2011

\begin{abstract}
The history of the interlaboratory comparison of TL dating results in Poland started in the 1980s. At that time the Lublin, Warsaw and Silesian laboratories made the first attempts at TL dating of the same loess samples from the Odonów profile. However, the cooperation ceased for many years due to great differences in the obtained TL age estimates. The next interlaboratory comparisons were made in the years 2000-2009 for the loess samples from several Polish (Dybawka, Tarnawce, Dankowice, Biały Kościół) and Ukrainian (Boyanychi, Halych, Velykyj Hlybochok, Yezupil) profiles. Most of the compared dates, obtained for the loess deposits from the Upper Pleistocene and younger part of the Middle Pleistocene, were consistent. This encouraged us to undertake the GdańskLublin interlaboratory cooperation in dating of 200-700 ka old loess deposits. Nine samples were taken from the Ukrainian profile Mamalyha 2 in 2009 for this purpose. The TL dating results indicate that comparable dates are obtained in two laboratories for loess deposits younger than $300 \mathrm{ka} \mathrm{BP}$. The TL signal obtained in the Gdańsk laboratory for the samples older than $300 \mathrm{ka}$ BP was saturated so such samples should not be dated by the multi-aliquot regeneration method. The results obtained in the Lublin laboratory for these deposits (489-682 ka) confirm that it is possible to date loess deposits older than $500 \mathrm{ka}$. It probably results from the use of total-bleach method with preheating at $160^{\circ} \mathrm{C}$ for the equivalent dose determination.
\end{abstract}

Keywords: TL dating, loess, Mesopleistocene, Pokuttya region.

\section{INTRODUCTION}

Experiments aimed at interlaboratory comparison of TL dating results in Poland have a long history. In 1984 the Quaternary Research Committee of the Polish Acad-

Corresponding author: J. Kusiak

e-mail: jaroslaw.kusiak@umcs.lublin.pl emy of Sciences financed the independent TL dating of the same 14 loess samples from the Odonów profile in the Lublin, Warsaw and Silesian (Gliwice) laboratories. In Lublin additive dose method was used and in Warsaw and Gliwice - regeneration method. The results obtained by additive method were considerably older than those obtained by the regeneration method (Bluszcz, 1987; Butrym, 1987; Prószyńska-Bordas et al., 1987). The next 
interlaboratory comparisons were made in the years 2000-2006. Loess samples from several Polish (Dybawka, Tarnawce, Dankowice, Biały Kościół) and Ukrainian (Halych, Velykyi Glybochok) profiles were TL dated in the Gdańsk laboratory and OSL (optically stimulated luminescence) dated in the Gliwice laboratory (Fedorowicz, 2006). Next attempt at interlaboratory comparison of the TL dating results was described by Fedorowicz et al. (2008) - the TL dates were obtained in the Gdańsk and Kiev laboratories for the Ukrainian loess profile at Boyanychi (Bojanice). In 2009, the Gdańsk and Lublin laboratories obtained TL dates for the Ukrainian loess profile at Yezupil (Łanczont et al., 2009). Most of the compared age estimates were consistent. In this paper we present another interlaboratory comparison of TL dating results. Nine samples were taken from the Ukrainian profile Mamalyha 2 in 2009 when it was presented during the $16^{\text {th }}$ Ukrainian-Polish Field Seminar entitled "The oldest loesses of the Podolia and Pokuttia regions: problems of origin, stratigraphy and palaeogeography". Samples were dated in the Gdańsk and Lublin laboratories.

\section{MAMALYHA LOESS SITE: LOCALISATION, LITHOLOGY, AND STRATIGRAPHY}

Mamalyha is a small village situated in the Pokucie region on the Prut River, almost at the meeting point of three state borders - Ukraine, Moldavia and Romania (Fig. 1). The research site occurs in the quarry where middle Miocene (Badenian) gypsum is exploited. Gypsum layers are exposed to a depth of about $30 \mathrm{~m}$. In places they are covered by the Ratyn limestone and clays. Distinct karst forms occur on the surface of calcareous rocks. Morphologically it is the Prut River high terrace rising almost $40 \mathrm{~m}$ above the valley bottom. The marine deposits are overlain by a cover of Pleistocene fluvial and loess deposits (Fig. 2). These deposits conceal the irregularities of karstified substratum.

The quarry excavation has an almost circular floor plan. The Quaternary deposits, exposed on its edges, are not very thick (about $8-10 \mathrm{~m}$ ). They are composed of loess-soil and fluvial series, in which four main units were distinguished. The loess-soil sequence is younger and varied in respect of stratigraphy. The rather typical and carbonate loess of the near-surface unit $\mathrm{I}$ is $2.5 \mathrm{~m}$

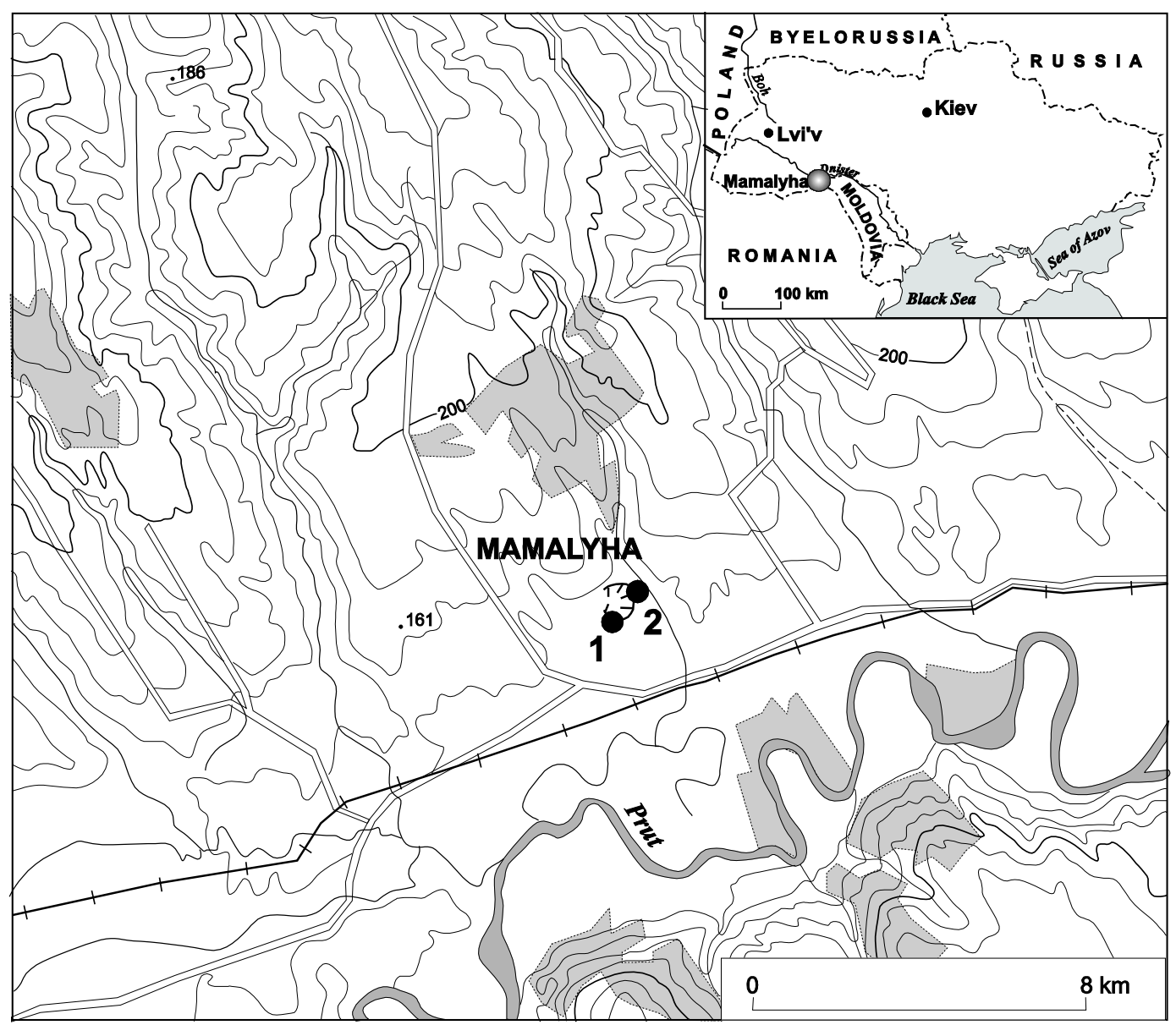

Fig. 1. Topographical sketch of the Mamalyha profile environs with location of research sites 1 and 2. 


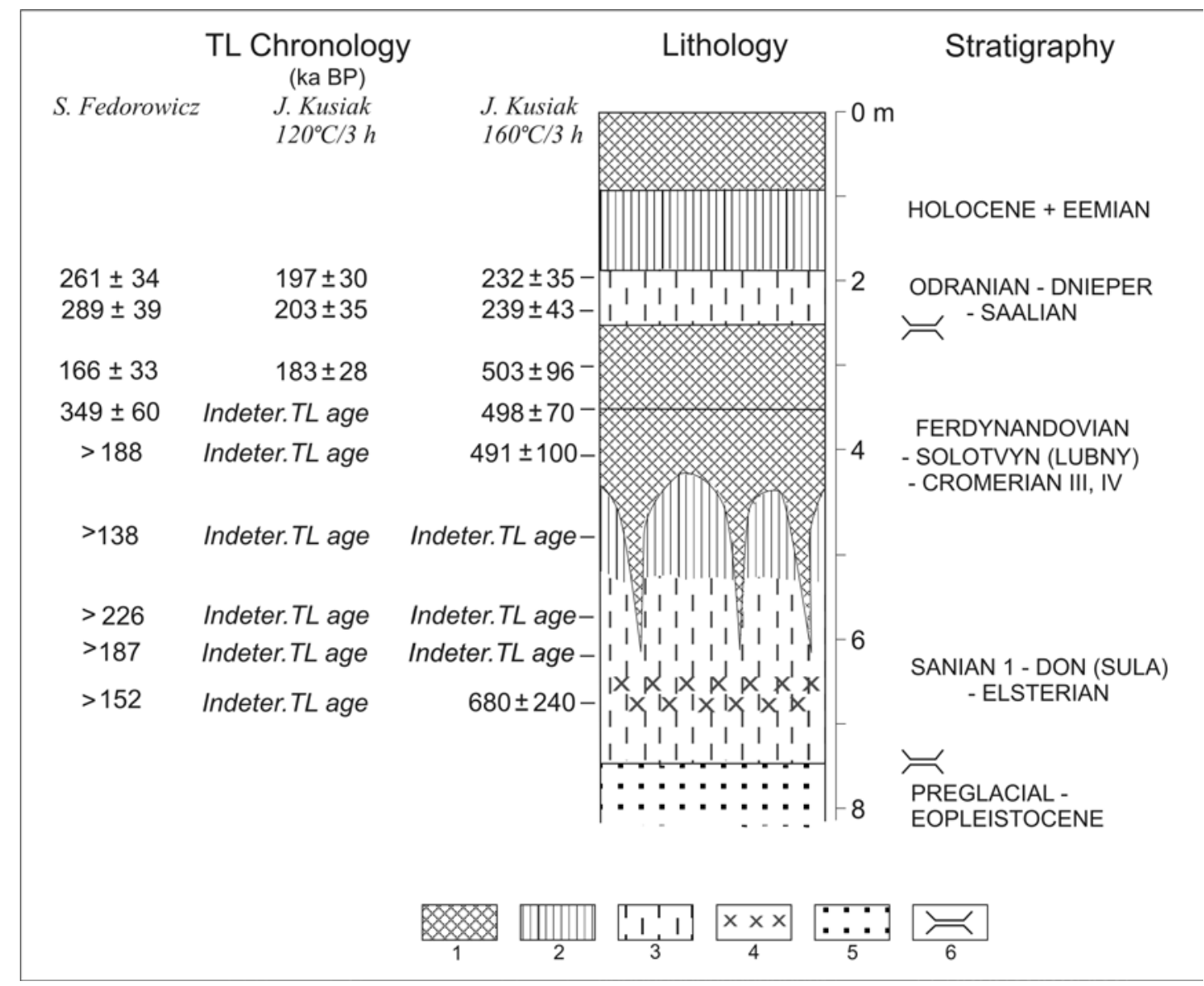

Fig. 2. Stratigraphic setting and thermoluminescence age of Pleistocene deposits in Mamalyha 2 profile. 1. A horizon of modern and fossil soils; 2. $B$ horizon of modern and fossil soils; 3. loess; 4. gley signs; 5. sandy and gravelly alluvia; 6 . hiatus

thick. The unit II is a pedocomplex with thick and almost black horizon of chernozem; this horizon is the key layer in the profile. This unit is almost completely preserved (Mamalyha 2 profile) or strongly denuded (Malmalyha 1 profile) in different parts of the quarry. The underlying unit III consists of about $2 \mathrm{~m}$ thick, loess deposits, which seem to be of subaqueous nature in their bottom part. The oldest unit IV (4-4.5 m thick fluvial series) is composed of obliquely stratified sands with gravels and silts deposited by the Prut River.

It should be stressed that the key layer of intra-loess pedocomplex - is very similar to the Solotvyn horizon in the Skala Podils'ka profile on the Zbruch River. Based on the detailed observations in the field and analyses, two superimposed soils of chernozem type were distinguished in this profile. The boundary between them is strongly obliterated due to advanced pedogenesis but several stages of this process were confirmed by the results of micromorphological and palynological analyses (Bogucki et al., 2009).

The stratigraphy of the loess-soil sequence in the Mamalyha, based on the analysis of the profile 1 and also on the comparison to the Skala Podil'ska profile, was correlated with the Quaternary stratigraphic schemes in Poland, Ukraine and Western Europe (Bogucki and Łanczont, 2009; Kusiak et al., 2011). The upper loess (unit I) was related to the Odranian (Dnieper) Glacial (Marine Isotope Stage or MIS 8) that evidenced a longlasting hiatus in the profile because the next unit II was correlated with the Solotvyn stratigraphic horizon (MIS 13-15) corresponding to the Ferdynandovian and Cormerian III and IV units of the Quaternary in Western Europe based on Gibbard et al. (1998). This name is accepted in the Prydnistrov'ja region (Bogucki and Łanczont, 2002); in the stratigraphic scheme of the Ukraine Quaternary this horizon is named Lubny (Gozhik et al., 1995). The underlying loess (unit III) was correlated with the Sula (Sanian 1/Don) Glacial (MIS16). The bottom alluvia (unit IV) were in general related to the Martonosha unit, i.e. Cromerian II (MIS 17-19).

\section{DESCRIPTION OF THE MAMALYHA 2 PRO- FILE}

In the long eastern wall of the exposure (Mamalyha 2 profile) the pedocomplex is much better developed, and it 
was the place from which samples were taken in 2009 for interlaboratory comparison of TL dating results. The additional objective was to determine the age of the Solotvyn soil because in the Mamalyha 1 profile only its root parts were dated, i.e. soil deposits filling fissure structures. The sequence exposed during preparatory work was given a preliminary description (Table 1). Loess layer, enriched with iron compounds, underlain by greenish-grey silts, is visible in the wall to a depth of about $8 \mathrm{~m}$.

\section{DESCRIPTION OF DATING METHOD}

The TL age of deposit is given by the following formula:

$\mathrm{t}=\mathrm{D}_{\mathrm{e}} / \mathrm{D}_{\mathrm{r}}$

where:

$D_{e}$ - equivalent dose is the laboratory dose of $\gamma$ or $\beta$ radiation, which produces the same thermoluminescence as that produced by the dose absorbed by the sample in natural conditions,

Table 1. Description of Mamalyha 2 profile.

\begin{tabular}{|c|c|}
\hline Depth (m) & Description \\
\hline \multicolumn{2}{|l|}{ Unit I } \\
\hline $0-2.6 \mathrm{~m}$ & $\begin{array}{l}\text { Loess with the Holocene soil in the top, homogeneous, } \\
\text { greyish, silty in the top, sandy in lower part, carbonate-free } \\
\text { except for the bottom (about } 0.5 \mathrm{~m} \text { thick) part. Erosion } \\
\text { boundary, sharp. } \\
\text { TL } 1-2.0 \mathrm{~m} \\
\text { TL } 2-2.4 \mathrm{~m}\end{array}$ \\
\hline \multicolumn{2}{|l|}{ Unit II } \\
\hline $2.6-5.6$ & $\begin{array}{l}\text { Interglacial pedocomplex of chernozem type composed of: } \\
\text { A horizon, } 2.0 \mathrm{~m} \text { thick, clayey, compact, dark brown, spotty, } \\
\text { with secondary carbonates, i.e. concretions. Distinct bound- } \\
\text { ary, uneven. } \\
\text { TL } 3-3.1 \mathrm{~m} \\
\mathrm{TL} 4-3.6 \mathrm{~m} \\
\mathrm{TL} 5-4.2 \mathrm{~m} \\
\text { BCa horizon, } 1 \mathrm{~m} \text { thick, light, greyish-brown, with numerous } \\
\text { carbonate concretions } 2-3 \mathrm{~cm} \text { in diameter, cut by fissures } \\
\text { several } \mathrm{cm} \text { wide, filled with humus material from the A } \\
\text { horizon. Boundary distinctly visible as colour change. } \\
\text { TL } 6-5.2 \mathrm{~m}\end{array}$ \\
\hline \multicolumn{2}{|l|}{ Unit III } \\
\hline $5.6-6.4$ & $\begin{array}{l}\text { Loess, blue-grey, clayey-sandy, with numerous carbonate } \\
\text { concretions } 2-3 \mathrm{~cm} \text { in diameter, which are horizontally } \\
\text { arranged in the lower part of the layer. Gradual transition. } \\
\text { TL } 7-6.2 \mathrm{~m}\end{array}$ \\
\hline $6.4-6.8$ & $\begin{array}{l}\text { Loess, yellow-rust-coloured, with many grey gley stains, } \\
\text { which are vertically elongated (traces of plant roots?), with } \\
\text { rust-coloured and black iron-manganese concretions. } \\
\text { Gradual transition. } \\
\text { TL } 8-6.7 \mathrm{~m}\end{array}$ \\
\hline $6.8-7.4$ & $\begin{array}{l}\text { Gley horizon, grey, with numerous, vertically elongated (5- } \\
10 \mathrm{~cm} \text { long), rust-coloured Liesegang rings. } \\
\text { TL } 9-7.2 \mathrm{~m}\end{array}$ \\
\hline
\end{tabular}

$D_{r}$ - dose rate is the effective dose of ionizing radiation absorbed by the examined sample in a year or millennium.

\section{Gdańsk laboratory}

Deposit moisture was measured in each sample, and after drying the dose rate $\left(D_{r}\right)$ was determined with the use of the MAZAR-95 gamma spectrometer. The concentrations of ${ }^{226} \mathrm{Ra},{ }^{228} \mathrm{Th},{ }^{40} \mathrm{~K}$ in a sample were obtained from twenty measurements lasting 2000 s each. The concentrations of radionuclides were converted into dose rates for alpha, beta and gamma radiation, assuming secular equilibria. Corrections were made for deposit moisture, dose of cosmic radiation, grain size and time of etching with HF (Aitken and Xie, 1983; Adamiec and Aitken, 1998). The uncertainty of dose rate $\left(D_{r}\right)$ determination was about 3\% (Poręba and Fedorowicz, 2005). The equivalent dose $\left(D_{\mathrm{e}}\right)$ was determined after the following pretreatment. The $80-100 \mu \mathrm{m}$ fraction was separated using a sieve method, treated with $10 \% \mathrm{HCl}$ for about twenty-four hours, with $2 \% \mathrm{NaOH}$ for the same time, and then with $40 \%$ HF for 45 minutes (Bluszcz, 2000). After each treatment a sample was washed with distilled water. A sample pretreated in this way was used to determine the equivalent dose $\left(\mathrm{D}_{\mathrm{e}}\right)$ by the TL multiplealiquot regeneration technique (Wintle and Prószyńska, 1983), according to the description published by Fedorowicz (2006). Glow curves were obtained using the RA'94 reader-analyser with the BG-39 filter. A sample was heated in argon atmosphere to $400^{\circ} \mathrm{C}$ with heating rate of $8^{\circ} \mathrm{C} / \mathrm{s}$.

Dating of deposits older than $100 \mathrm{ka}$ by regeneration method arouses controversy. The problem of sensivity changes is discussed among others by Berger (1994), Berger et al. (1992), Berger et al. (1994), Li and Wintle (1992), Zhou and Wintle (1994). These changes are probably caused by long bleaching and result in a considerably underestimation of TL age. Frechen (1992; 1999) finds that regeneration method can give underestimated results for deposits older than $100 \mathrm{ka}$ but not for all dated samples. Kusiak (2002) finds that such underestimation can occur when the equivalent dose is determined by regeneration method as well as total-bleach method but the scale or absence of underestimation is dependent on the procedure of preliminary heating. The results of TL dating of loess samples from the Zahvizja profile (in which the Bruhnes/Matuyama boundary occurs) indicate that regeneration method with preheating at $105^{\circ} \mathrm{C}$ for 3 hours gives the maximum values of equivalent dose about 800 Gy (i.e. TL age about $250 \mathrm{ka}$ ) even for the deposits with the expected age about $800 \mathrm{ka}$, and the same method with preheating at $160^{\circ} \mathrm{C}$ for 3 hours gives 1000 Gy (about $300 \mathrm{ka}$ ). In case of total-bleach method and preheating at $105^{\circ} \mathrm{C}$ for 3 hours a consistent increase of equivalent dose value is observed with the profile depth to about 1300 Gy (about $400 \mathrm{ka}$ ). However, this value 
was obtained for the deposits with the Bruhnes/Matuyama boundary so the results are underestimated. According to Berger and Anderson (1994) and Van den Haute et al. (2003) the laboratory high temperature storage (over $150^{\circ} \mathrm{C}$ ) of subsamples before TL readout minimizes age underestimation resulting from unstable thermoluminescence induced by laboratory irradiation of samples with high doses of ionizing radiation. This opinion was confirmed by the TL dating results of samples from the Zahvizdja profile. Total-bleach method with preheating at $160^{\circ} \mathrm{C}$ for 3 hours gave TL dates exceeding $700 \mathrm{ka}$, and equivalent dose as well as TL age consistently increased with depth (Kusiak et al., 2002). The TL age estimates obtained with preheating at $160^{\circ} \mathrm{C}$ were consistently higher than those obtained with preheating at $105^{\circ} \mathrm{C}$, which constituted $60-75 \%$ of the former ones. The only deficiency of the dates obtained with strong preheating was high uncertainty of measurements, which exceeded $30 \%$.

\section{Lublin laboratory}

\section{Determination of the equivalent dose $D_{e}$}

The equivalent dose was determined by the totalbleach method described by Singhvi et al. (1982). From the total mass of each sample the $45-63 \mu \mathrm{m}$ polymineral fraction was separated, and then treated with $10 \% \mathrm{HCl}$ to remove carbonates and with $30 \% \mathrm{H}_{2} \mathrm{O}_{2}$ to remove organic material (Balescu et al., 1991). Then, the mineral material obtained from each sample was divided into eight portions. One portion was used to determine the natural thermoluminescence. Second portion was exposed to light from an ultraviolet lamp of OSRAM ULTRAVITALUX type for about 12 hours, in order to determine the residual level of thermoluminescence. The remaining six portions were irradiated with the ionising radiation doses from a ${ }^{60} \mathrm{Co} \gamma$ source, maximally to 5000 Gy (Berger et al., 1992). In order to determine the $\mathrm{D}_{\mathrm{e}}$ value, thirty samples of $4 \mathrm{mg}$ in weight were taken from each portion. The glow curves were recorded using a TL reader/analyser the RA'94 type (with the EMI 9789 QA photomultiplier) linked with an IBM computer. A sample was heated in argon atmosphere to $400^{\circ} \mathrm{C}$ with heating rate of $10^{\circ} \mathrm{C} / \mathrm{s}$. The BG-28 optical filter was used (Berger et al., 1992). Before the TL measurements subsamples were preheated at $120^{\circ} \mathrm{C}$ for 3 hours (series A) or $160^{\circ} \mathrm{C}$ for 3 hours (series B). Thermoluminescence light sum was read as the surface area under the $240-250^{\circ} \mathrm{C}$ or 270 $280^{\circ} \mathrm{C}$ region of the $\mathrm{TL}$ glow curve, which included its maximum (Kusiak, 2008). An exponential function was fitted to the obtained points with the use of the FIT-SIM programme (Grün, 1994), which was based on the simplex fitting procedures and analytical error calculation described by Brumby (1992). Anomalous fading did not occur probably because irradiation of samples (in Institute of Nuclear Chemistry and Technology, Warszawa,
Poland) and thermoluminescence measurements were carried out several months apart.

\section{Determination of dose rate $D_{r}$}

Dose rate for the 45-63 $\mu \mathrm{m}$ grain fraction was calculated using the following formula:

$D_{\mathrm{r}}=\mathrm{k} \mathrm{ad}_{\alpha}+\mathrm{d}_{\beta}+\mathrm{d}_{\gamma}+\mathrm{d}_{\mathrm{c}}$

where:

$\mathrm{k}=0.1$ indicates the effectiveness of generating thermoluminescence when subjected to $\alpha$ radiation;

$\mathrm{a}=0.5$ is a correction due to the fact that grains of about $50 \mu \mathrm{m}$ in diameter can receive only $50 \%$ of the $\alpha$ radiation dose received in the same deposit by grains of $10 \mu \mathrm{m}$ and less in diameter (Wintle, 1987);

$d_{\alpha}, d_{\beta}, d_{\gamma}, d_{c}-$ doses from $\alpha, \beta, \gamma$ and cosmic radiation, respectively.

Dose rates $d_{\alpha}, d_{\beta}, d_{\gamma}$ were calculated from the measured concentrations of natural radionuclides $\left({ }^{40} \mathrm{~K},{ }^{226} \mathrm{Ra}\right.$,

${ }^{228} \mathrm{Th}$ ). The measurements were carried out in the laboratory using a three-channel, stationary gamma spectrometer type MAZAR-95 produced by Polon-Zot Warszawa (Poland) with a lead housing with $5 \mathrm{~cm}$ thick walls, assuming age equilibrium state in the radioactive series. Forty measurements were taken per sample, with the measurement time for each being $2000 \mathrm{~s}$. The concentrations of radioisotopes in $\mathrm{Bq} / \mathrm{kg}$ were converted into absorbed dose rates for $\alpha, \beta$ and $\gamma$ radiation, based on the data published by Aitken (1998). $\mathrm{D}_{\mathrm{c}}$ was calculated on the basis of data published by Prescott and Hutton (1988). Correction for deposit moisture was calculated after Berger (1988).

\section{TL DATING RESULTS}

The results of TL dating obtained in the Gdańsk laboratory are listed in Tables 2 and 3 . The TL ages of two samples from the upper unit I are very similar $(261 \pm 34 \mathrm{ka}$ and $286 \pm 39 \mathrm{ka}$ ). They support the idea that loess of the unit I was deposited during the Odra Glacial. The unit II (the Solotvyn pedocomplex) was TL dated at $167 \pm 33 \mathrm{ka}$ and $349 \pm 60 \mathrm{ka}$. These results are distinctly underestimated compared to the expected stratigraphic age. Such underestimation could have resulted from the changes of sensivity caused by long bleaching and lack of preheating (see subsection 4). The TL dating of five other samples from the Mamalyha profile in the Gdańsk laboratory was unsuccessful because their TL signal was saturated.

Two series of the TL dating results obtained in the Lublin laboratory are listed in Table 3 . The dates obtained with preheating at $120^{\circ} \mathrm{C}$ for 3 hours were denoted as series $\mathrm{A}$, and those with $160^{\circ} \mathrm{C}$ for 3 hours - as series B. Loess of the unit I was dated in series A at $197 \pm 30 \mathrm{ka}$ (Lub-4757) and 203 $\pm 35 \mathrm{ka}$ (Lub-4758), and in series B at $232 \pm 35 \mathrm{ka}$ (Lub-4757) and 239 $\pm 43 \mathrm{ka}$ (Lub-4758). Based 
M. Łanczont et al.

Table 2. Average K-40, Ra-226, Th-228 activities measured by gamma spectrometry. Estimation of dose rate.

\begin{tabular}{|c|c|c|c|c|c|}
\hline Depth (m) & Lab. No & $\begin{array}{c}\mathrm{K}-40 \\
(\mathrm{~Bq} / \mathrm{kg})\end{array}$ & $\begin{array}{l}\text { Ra-226 } \\
\text { (Bq/kg) }\end{array}$ & $\begin{array}{l}\text { Th-228 } \\
\text { (Bq/kg) }\end{array}$ & $\begin{array}{l}\text { Dose rate } \\
D_{\mathrm{r}}(\text { Gy/ka) }\end{array}$ \\
\hline \multicolumn{6}{|c|}{ Gdańsk laboratory } \\
\hline 2.00 & UG-6198 & $482.1 \pm 7.0$ & $38.2 \pm 1.8$ & $36.2 \pm 2.4$ & $3.40 \pm 0.31$ \\
\hline 2.40 & UG-6199 & $468.4 \pm 7.2$ & $40.1 \pm 1.9$ & $36.8 \pm 2.5$ & $3.38 \pm 0.32$ \\
\hline 3.10 & UG-6200 & $420.9 \pm 8.4$ & $35.4 \pm 2.1$ & $31.6 \pm 2.9$ & $2.99 \pm 0.29$ \\
\hline 3.60 & UG-6201 & $463.9 \pm 7.4$ & $29.2 \pm 2.3$ & $35.0 \pm 3.0$ & $3.20 \pm 0.36$ \\
\hline 4.20 & UG-6202 & $469.9 \pm 8.2$ & $28.9 \pm 2.0$ & $33.5 \pm 2.7$ & $3.18 \pm 0.33$ \\
\hline 5.20 & UG-6203 & $412.8 \pm 9.0$ & $27.6 \pm 1.6$ & $32.7 \pm 2.8$ & $2.89 \pm 0.30$ \\
\hline 6.20 & UG-6204 & $421.9 \pm 8.3$ & $29.0 \pm 2.0$ & $23.0 \pm 2.4$ & $2.65 \pm 0.27$ \\
\hline 6.70 & UG-6205 & $501.2 \pm 9.8$ & $33.6 \pm 2.0$ & $30.0 \pm 2.9$ & $3.20 \pm 0.33$ \\
\hline 7.20 & UG-6206 & $406.0 \pm 7.3$ & $30.8 \pm 2.6$ & $24.2 \pm 2.6$ & $2.63 \pm 0.28$ \\
\hline \multicolumn{6}{|c|}{ Lublin laboratory } \\
\hline 2.00 & Lub-4757 & $425.6 \pm 51.0$ & $30.5 \pm 9.5$ & $33.1 \pm 5.0$ & $3.08 \pm 0.20$ \\
\hline 2.40 & Lub-4758 & $405.1 \pm 51.6$ & $34.1 \pm 10.0$ & $32.5 \pm 5.1$ & $3.11 \pm 0.22$ \\
\hline 3.10 & Lub-4759 & $373.7 \pm 48.2$ & $27.4 \pm 9.2$ & $29.7 \pm 4.8$ & $2.75 \pm 0.20$ \\
\hline 3.60 & Lub-4760 & $405.3 \pm 47.9$ & $21.0 \pm 8.5$ & $32.6 \pm 4.7$ & $2.75 \pm 0.19$ \\
\hline 4.20 & Lub-4761 & $424.8 \pm 51.1$ & $21.4 \pm 9.1$ & $32.6 \pm 5.0$ & $2.82 \pm 0.20$ \\
\hline 5.20 & Lub-4762 & $376.8 \pm 46.2$ & $20.6 \pm 8.4$ & $28.0 \pm 4.5$ & $2.53 \pm 0.19$ \\
\hline 6.20 & Lub-4763 & $378.3 \pm 33.2$ & $24.0 \pm 5.2$ & $24.7 \pm 2.9$ & $2.45 \pm 0.12$ \\
\hline 6.70 & Lub-4764 & $433.3 \pm 49.2$ & $27.4 \pm 8.7$ & $29.0 \pm 4.6$ & $2.92 \pm 0.20$ \\
\hline 7.20 & Lub-4765 & $358.3 \pm 44.7$ & $25.4 \pm 8.4$ & $22.2 \pm 4.2$ & $2.46 \pm 0.19$ \\
\hline
\end{tabular}

Table 3. Results of $T L$ dating.

\begin{tabular}{|c|c|c|c|c|}
\hline Depth (m) & Lab. No & $\begin{array}{l}\text { Dose rate } \\
\text { Dr (Gy/ka) }\end{array}$ & Equivalent dose $D_{e}(G y)$ & $\begin{array}{c}\text { TL age } \\
\text { (ka) }\end{array}$ \\
\hline \multicolumn{5}{|c|}{ Gdańsk laboratory } \\
\hline 2.00 & UG-6198 & $3.40 \pm 0.31$ & $888 \pm 90$ & $261 \pm 34$ \\
\hline 2.40 & UG-6199 & $3.38 \pm 0.32$ & $970 \pm 100$ & $286 \pm 39$ \\
\hline 3.10 & UG-6200 & $2.99 \pm 0.29$ & $499 \pm 56$ & $167 \pm 33$ \\
\hline 3.60 & UG-6201 & $3.20 \pm 0.36$ & $1110 \pm 120$ & $349 \pm 60$ \\
\hline 4.20 & UG-6202 & $3.18 \pm 0.33$ & $>600.0$ & $>188$ \\
\hline 5.20 & UG-6203 & $2.89 \pm 0.30$ & $>400.0$ & $>138$ \\
\hline 6.20 & UG-6204 & $2.65 \pm 0.27$ & $>600.0$ & $>226$ \\
\hline 6.70 & UG-6205 & $3.20 \pm 0.33$ & $>600.0$ & $>187$ \\
\hline 7.20 & UG-6206 & $2.63 \pm 0.28$ & $>400.0$ & $>152$ \\
\hline \multicolumn{5}{|c|}{ Lublin laboratory - preheating at $120^{\circ} \mathrm{C}$ for 3 hours } \\
\hline 2.00 & Lub-4757 & $3.08 \pm 0.20$ & $607 \pm 85$ & $197 \pm 30$ \\
\hline 2.40 & Lub-4758 & $3.11 \pm 0.22$ & $631 \pm 95$ & $203 \pm 35$ \\
\hline 3.10 & Lub-4759 & $2.75 \pm 0.20$ & $503 \pm 67$ & $183 \pm 28$ \\
\hline 3.60 & Lub-4760 & $2.75 \pm 0.19$ & Saturation TL & Indeterminable TL age \\
\hline 4.20 & Lub-4761 & $2.82 \pm 0.20$ & Saturation TL & Indeterminable TL age \\
\hline 5.20 & Lub-4762 & $2.53 \pm 0.19$ & Saturation TL & Indeterminable TL age \\
\hline 6.20 & Lub-4763 & $2.45 \pm 0.12$ & Saturation TL & Indeterminable TL age \\
\hline 6.70 & Lub-4764 & $2.92 \pm 0.20$ & Saturation TL & Indeterminable TL age \\
\hline 7.20 & Lub-4765 & $2.46 \pm 0.19$ & Saturation TL & Indeterminable TL age \\
\hline \multicolumn{5}{|c|}{ Lublin laboratory - preheating at $160^{\circ} \mathrm{C}$ for 3 hours } \\
\hline 2.00 & Lub-4757 & $3.08 \pm 0.20$ & $714 \pm 95$ & $232 \pm 35$ \\
\hline 2.40 & Lub-4758 & $3.11 \pm 0.22$ & $740 \pm 120$ & $239 \pm 43$ \\
\hline 3.10 & Lub-4759 & $2.75 \pm 0.20$ & $1380 \pm 240$ & $503 \pm 96$ \\
\hline 3.60 & Lub-4760 & $2.75 \pm 0.19$ & $1370 \pm 170$ & $498 \pm 70$ \\
\hline 4.20 & Lub-4761 & $2.82 \pm 0.20$ & $1380 \pm 280$ & $490 \pm 100$ \\
\hline 5.20 & Lub-4762 & $2.53 \pm 0.19$ & Saturation TL & Indeterminable TL age \\
\hline 6.20 & Lub-4763 & $2.45 \pm 0.12$ & Saturation TL & Indeterminable TL age \\
\hline 6.70 & Lub-4764 & $2.92 \pm 0.20$ & Saturation TL & Indeterminable TL age \\
\hline 7.20 & Lub-4765 & $2.46 \pm 0.19$ & $1680 \pm 560$ & $680 \pm 240$ \\
\hline
\end{tabular}


on the results of series A, these deposits were accumulated during the penultimate glacial (younger part of the Saalian Glacial), and the results of series B indicated the Odranian-Dnieper Glacial (older part of the Saalian Glacial) Three samples for TL dating were taken from the Solotvyn pedocomplex of the unit II. In the series A only one date was obtained (183 $\pm 28 \mathrm{ka}-$ Lub-4759), which was very underestimated compared to the expected age. For two other samples the TL signal was saturated. Three dates obtained in series B (Lub-4759 - Lub-4761; $503 \pm 96 \mathrm{ka}, 498 \pm 70 \mathrm{ka}$ and $490 \pm 100 \mathrm{ka})$ are stratigraphically reasonable. Four samples from the deposits underlying the unit II were dated (Lub-4762 - Lub-4765) but only one TL age $(680 \pm 240 \mathrm{ka})$ was obtained in series B for the lowest sample from the unit III related to the (Sanian 1/Don ) Glacial. The TL signal of the other samples was saturated.

\section{PALAEOGEOGRAPHICAL AND STRATI- GRAPHICAL IMPLICATIONS}

In the light of the TL dating we can infer that the deposit cover on the high terrace of the Prut River was formed in two stages separated by a long interruption.

It seems that the older stage was relatively continuous. Fluvial deposition on the marine deposits can be most probably related to the Małopolanian Interglacial, which is generally correlated with the Martonosha warm period - distinguished in Ukraine. We can observe in the profile that the deposition of channel sands and gravels was replaced by the sedimentation of subaqueous muds of flood facies, and then the Sula loess deposits. The transition between the bottom alluvial series and loess deposits is also gradual. The Solotvyn/Lubny pedocomplex is developed on this loess substratum. Therefore, the whole soil-loess-alluvial sequence can be correlated with the West European unit named the Cromerian complex. The upper loess (unit I) can be related to the Odra (Dnieper) Glacial so it is evident that a long-lasting hiatus occurs in the profile. This prolonged lack of preserved sedimentation on the Prut River terrace fell on a considerable part of the Mesopleistocene, which included the MIS 12-9 interval. This period included the San 2 Glacial (with the maximum extent of the Scandinavian ice sheet in Central Europe) and the Holstenian s.l. Interglacial. It should be noticed that the deposits of this age are lacking on the high terraces of rivers in the whole Podillya and Pokuttya regions. This fact can be explained by weak aeolian deposition, and also by intensive denudation processes, which is indirectly evidenced by the occurrence of two erosion surfaces within the Solotvyn pedocomplex, and a third one in its top. The erosion processes left only these parts of the Solotvyn soil catena, which filled concave forms of relief, e.g. karst dolines. The deposits of the Lublinian-Wartanian interglacial-glacial cycle are absent, and the surface soil can contain the relict elements of the Eemian soil.

\section{FINAL REMARKS AND CONCLUSIONS}

Experience gained during the experiment of parallel dating of the Mesopleistocene deposits from the Mamalyha 2 profile is positive from methodological and research aspects. Two different procedures of the TL method, used in the Gdańsk and Lublin laboratories, were tested. Stratigraphically reasonable results, obtained with the use of total-bleach method, confirmed its usefulness for dating of loess deposits from the Brunhes epoch.

The TL dating results indicate that:

1) The dose rate values obtained in the Gdańsk and Lublin laboratories with the use of the MAZAR-95 gamma spectrometer are similar within error limits.

2) Similar values of TL ages for the unit I obtained in Gdańsk and Lublin (series B) indicate that stratigraphically consistent results could be obtained in different laboratories for loess deposits younger than about $300 \mathrm{ka}$.

3) The TL signal obtained in the Gdańsk laboratory for the samples older than $300 \mathrm{ka} \mathrm{BP}$ was saturated. This fact suggests that such samples should not be dated by the multi aliquot regeneration method (Fedorowicz, 2006).

4) The TL ages obtained with preheating at $120^{\circ} \mathrm{C}$ (and $105^{\circ} \mathrm{C}$ ) are usually considerably younger than those obtained with preheating at $160^{\circ} \mathrm{C}$. They are also usually strongly underestimated compared to the expected age. Therefore, weak preheating can result in wrong stratigraphic interpretation of dated deposits.

5) The TL results obtained in the Lublin laboratory for the units II and III suggests that it is possible to date the regional loess deposits older than $500 \mathrm{ka} \mathrm{BP}$. It probably results from the use of total-bleach method with preheating at $160^{\circ} \mathrm{C}$ for the equivalent dose determination.

6) The TL signal of the samples Lub-4762 - Lub-4764 (series B) was saturated and their TL ages were not determined. It is difficult to identify the reasons for this observation without detailed studies. However, it can be supposed that it was connected with mineral composition of deposits. Mejdahl (1986) states that the saturated TL signal for quartz corresponds to the dose of ionizing radiation about $400 \mathrm{~Gy}$, i.e. to the TL age about $160 \mathrm{ka}$, and for potassium feldspars about $3000 \mathrm{~Gy}$. It appears that for the saturated TL samples, probably either feldspars were absent or the TL was dominated by quartz signals. Saturation of TL signal for samples Lub-4760 - Lub-4765 (series A) could have resulted from the lack of long-term stability of TL signal for emission wavelength responsible for thermoluminescence occurring in temperature $240-250^{\circ} \mathrm{C}$ of glow curve (Berger et al. 1992, Berger 1994).

7) Attempts at thermoluminescence dating of deposits older than $500 \mathrm{ka}$ (both loess and aeolian sandy deposits) were made many times (among others: Fre- 
chen, 1999; Frechen et al., 1999; Huntley et al., 1994; Rhodes et al., 2006). In the last years the new technique (TT-OSL) has been tested for dating of very old loess deposits (Wang et al., 2006a; 2006b). However, the first reliable results of thermoluminescence dating of loess up to $800 \mathrm{ka}$ old from New Zealand were published by Berger et al. (1992). Geological deposits with so high dose rate as loess were also successfully dated in the Atapuerca site in Spain (Berger et al., 2008). The possibility of obtaining such high values of TL age gives new prospects of using the thermoluminescence method in the research on aeolian Mid-Pleistocene deposits.

8) In the Lublin laboratory the TL ages older than 500000 years were obtained once again. In the last years such results were obtained for loess profiles in Zahvizdja, Vendychany, Skala Podils'ka and Mamalyha 1 (Bogucki et al., 2009; Kusiak et al., 2002; Kusiak et al., 2011).

9) The TL dating results obtained for the mentioned Ukrainian profiles enables to extend chronological frames to the Mesopleistocene period in this part of Central Europe.

\section{ACKNOWLEDGEMENTS}

The authors owe much to helpful suggestions and valuable comments by the both reviewers that significantly improved the manuscript. We would like to express our gratitude to Ewa Sadowska for the graphic preparation of the figures and to Dr Maria Wilgat who prepared the English version of this paper.

\section{REFERENCES}

Adamiec G and Aitken MJ, 1998. Dose-rate conversion factors: update. Ancient TL 16: 37-50.

Aitken MJ, 1998. An introduction to optical dating. Oxford University Press: $267 \mathrm{pp}$.

Aitken MJ and Xie J, 1983. Moisture correction for annual gamma dose. Ancient TL 8: 6-9.

Balescu S, Packman SC and Wintle AG, 1991. Chronological separation of interglacial raised beaches from Northwestern Europe using thermoluminescence. Quaternary Research 35(1): 91-102, DOI 10.1016/0033-5894(91)90097-O.

Berger GW, 1988. Dating Quaternary events by luminescence. Geological Society of America, Special Paper 227: 13-50.

Berger GW, 1994. Thermoluminescence dating of sediments older then $\sim 100$ ka. Quaternary Science Reviews 13(5-7): 445-455, DOI 10.1016/0277-3791(94)90057-4.

Berger GW, Pillans BJ and Palmer AS, 1992. Dating loess up to $800 \mathrm{ka}$ by thermolumines-cence. Geology 20(5): 403-406, DOI 10.1130/0091-7613(1992)020<0403:DLUTKB >2.3.CO;2.

Berger GW, Pillans BJ and Palmer AS, 1994. Test of thermoluminescence dating of loess from New Zealand and Alaska. Quaternary Science Reviews 13(4): 309-333, DOI 10.1016/02773791(94)90110-4.

Berger GW and Anderson PM, 1994. Thermoluminescence dating of an Arctic lake core from Alaska. Quaternary Science Reviews 13(57): 497-501, DOI 10.1016/0277-3791(94)90065-5.

Berger GW, Pérez-González A, Carbonell E, Arsuaga JL, Bermúdez de Castro J-M and $\mathrm{Ku} \mathrm{T}-\mathrm{L}, 2008$. Luminescence chronology of cave sediments at the Atapuerca paleoanthropological site, Spain. Journal of Human Evolution 55(2): 300-311, DOI 10.1016/j.jhevol.2008.02.012.

Bluszcz A, 1987. Sprawozdanie $z$ datowania termoluminescencyjnego próbek lessu z Odonowa. (Report on thermoluminescence dating of loess samples from Odonów). Sprawozdania z badań naukowych KBN 7: 8-9 (in Polish).

Bluszcz A, 2000. Datowanie luminescencyjne osadów czwartorzędowych - teoria, ogranicze-nia, problemy interpretacyjne. Zeszyty Naukowe Politechniki Ślaskiej, seria Mat. Fiz., Z. 86, Geochronometria 17: 104pp (in Polish).

Bogucki (Boguckyj) AB and Łanczont M, 2002. Stratygrafia lessów Naddniestrza Halickiego (Loess stratigraphy in the Halyč Prydnistrov'ja region). In: Madeyska T, ed., Lessy i paleolit Naddniestrza halickiego (Ukraina) (Loess and Palaeolithic of the Dniester River Basin, Halyč region (Ukraine)). Studia Geologica Polonica 119: 315-327 (in Polish).

Bogucki (Boguckij) A and Łanczont M, 2009. Rozriz plejstocenowich widkładiw Mamałyga na Pokutti (The profile of Pleistocene deposits in the Mamalyha site in the Pokuttya region). In: Bogucki A, ed., Najdawnyszi lesi Podilija o Pokutitja, problemy genezy, stratygrafii, paleogeografii (The oldest loesses of the Podillya and Pokuttya regions: problems of origin, stratigraphy and palaeogeography). Wyd. Centr. LUN im. I. Franko, Lviv: 147-193 (in Ukrainian).

Bogucki (Boguckyj) AB, Łanczont M, Łącka B, Madeyska T and Nawrocki J, 2009. Quaternary sediment sequence at Skala Podil'ska, Dniester River basin (Ukraine): Preliminary results of multi-proxy analyses. Quaternary International 198(1-2): 173194, DOI 10.1016/j.quaint.2008.05.010.

Brumby S, 1992. Regression analysis of ESR/TL dose-response data. Nuclear Tracks and Radiation Measurement 20(4): 595-599, DOI 10.1016/1359-0189(92)90010-S.

Butrym J, 1987. Wiek TL lessów z profilu w Odonowie k/ Kazimierzy Wielkiej (TL age of loesses from the Odonów profile near Kazimierza Wielka). Sprawozdania z badań naukowych KBN 7: 10-15 (in Polish).

Fedorowicz S, 2006. Metodyczne aspekty luminescencyjnego oznaczania wieku osadów neoplejstoceńskich Europy Środkowej (Methodological aspects of luminescence dating of Central Europe's Neopleistocene deposits). Wydawnictwo Uniwersytetu Gdańskiego: $156 \mathrm{pp}$ (in Polish).

Fedorowicz S, Prylypko S, Bogucki A and Łanczont M, 2008. Międzylaboratoryjne porówna-nie dat termoluminescencyjnych (TL) próbek z profilu Bojanice (Ukraina) (Interlaboratory comparison of thermoluminescence (TL) ages of samples from the Boyanychi profile (Ukraine)). Book of abstracts XV Konferencja "Stratygrafia plejstocenu Polski" Zakopane 1-5 September 2008: 92-95 (in Polish).

Frechen M, 1992. Systematic thermoluminescence dating of two loess profiles from the Mid-dle Rhine Area (F.R.G.). Quaternary Science Reviews 11(1-2): 93-101, DOI 10.1016/0277-3791(92)90048$\mathrm{D}$.

Frechen M, 1999. Upper Pleistocene loess stratigraphy in Southern Germany. Quaternary Science Reviews 18(2): 243-269, DOI 10.1016/S0277-3791(98)00058-4.

Frechen M, Zander A, Cilek V and Ložek V, 1999. Loess chronology of the Last Interglacial /Glacial cycle in Bohemia and Moravia, Czech Republic. Quaternary Science Reviews 18(13): 1467-1493, DOI 10.1016/S0277-3791(98)00087-0.

Gibbard PL, Zalasiewicz JA and Mathers SJ, 1998. Stratigraphy of the marine Plio-Pleisto-cene crag deposits of East Anglia. Meded. $\mathrm{Ne}$ derl. Inst. v. Toegepaste Geowetensch. TNO 60: 239-262.

Gozhik P, Shelkoplyas V and Khristophorova T, 1995. Development stages of loessial and glacial formations in Ukraine. Stratigraphy of Loesses in Ukraine. Annales UMCS, sec. B, 50: 65-74.

Grün R, 1994. Fit-Sim. Computer program, QDRC, Canberra.

Huntley D J, Hutton JT and Prescott JR, 1994. Further thermoluminescence dates from the dune sequence in the south-east of South Australia. Quaternary Science Reviews 13(3): 201-207, DOI 10.1016/0277-3791(94)90025-6. 
Kusiak J, 2002. Problem wyboru procedury pomiarowej w analizie termoluminescencyjnej na przykładzie datowania profilu Zahvizdja (Selection of measurement method in the TL analysis on the basis of dating of the Zahvizdja profile). In: T. Madeyska, ed., Lessy i paleolit Naddniestrza halickiego (Ukraina) (Loess and Palaeolithic of the Dniester River Basin, Halyč region (Ukraine)). Studia Geologica Polonica 119: 193-197.

Kusiak J, 2008. Kontekst stratygraficzny zastosowania różnych odmian metody termolumi-nescencyjnej w datowaniu lessów z terenu Polski południowo-wschodniej i Ukrainy północno-zachodniej (Stratigraphic context of the application of different variants of thermoluminescence method to dating of loesses from the southeastern Poland and northwestern Ukraine). Annales UMCS, Sec.B, 63: 2160.

Kusiak J, Łanczont M, Bogucki (Boguckyj) A and Wojtanowicz J, 2002. Divergence in the TL dating resulting from different methods of equivalent dose determination. Geochronometria 21: 27-32.

Kusiak J, Łanczont M, Madeyska T and Bogucki AB, 2011. Problems of TL dating of the Mesopleistocene loess deposits in the Podillya and Pokuttya regions (Ukraine). Geochronometria this volume, DOI 10.2478/s13386-011-0026-5.

Li S-H and Wintle AG, 1992. Luminescence sensitivity change due to bleaching of sediments. Nuclear Tracks and Radiation Measurments 20(4): 567-573, DOI 10.1016/1359-0189(92)90006-H.

Łanczont M, Fedorowicz S, Kusiak J, Bogucki (Boguckij) A and Sytnyk A, 2009. TL age of loess deposits in the Yezupil I Palaeolithic site on the upper Dniester River (Ukraine). Geologija 51, 3-4 (67-68): 86-96.

Mejdahl V, 1986. Thermoluminescence dating of sediments. Radiation Protection Dosimetry 17(1-4): 219-227.

Poręba GJ and Fedorowicz S, 2005. Gamma spectrometry for OSL and TL dating of loess deposits at Dybawka and Tarnawce (SE Poland). Geochronometria 24: 27-32.

Prószyńska-Bordas H, Stańska-Prószyńska W and Prószyński M, 1987. Termoluminescencyjne wskaźniki wieku lessów i gleb kopalnych z przekroju w Odonowie (metoda i wyniki laboratorium warszawskiego) (Thermoluminescence indicators of age of loesses and paleosols from the Odonów profile (Warsaw laboratory method and results)). Sprawozdania z badań naukowych KBN 7: 16-29 (in Polish).

Prescott JR and Hutton JT, 1988. Cosmic ray i gamma ray dosimetry for TL and ESR. Nuclear Tracks 14(1-2): 223-227, DOI 10.1016/1359-0189(88)90069-6.

Rhodes EJ, Singarayer JS, Raynal J-P, Westaway KE and Sbihi-Alaoui FZ, 2006. New age estimates for the Palaeolithic assemblages and Pleistocene succession of Casablanca, Morocco. Quaternary Science Reviews 25(19-20): 2569-2585, DOI 10.1016/j.quascirev.2005.09.010.

Singhvi AK, Sharma YP and Agrawal DP, 1982. Thermoluminescence dating of sand dunes in Rajastan, India. Nature 295(5847): 313315, DOI 10.1038/295313a0.

Van den Haute P, Frechen M, Buylaert J-P, Vandenberghe D and De Corte F, 2003. The Last Interglacial palaeosol in the Belgian loess belt TL age record. Quaternary Science Reviews 22(10-13): 985990, DOI 10.1016/S0277-3791(03)00023-4.

Wang XL, Lu YC and Wintle AG, 2006a. Recuperated OSL dating of fine grained quartz in Chinese loess. Quaternary Geochronology 1(2): 89-100, DOI 10.1016/j.quageo.2006.05.020

Wang XL, Wintle AG and Lu YC, 2006b. Thermally transferred luminescence in fine-grained quartz from Chinese loess: basic observations. Radiation Measurements 41(6): 649-658, DOI 10.1016/j.radmeas.2006.01.001.

Wintle AG, 1987. Themoluminescence dating of loess. Catena Supplement 9: 103-115.

Wintle AG and Prószyńska H, 1983. TL dating of loess in Germany and Poland. PACT 9: 547-554.

Zhou LP and Wintle AG, 1994. Sensitivity change of thermoluminescence signals after labo-ratory optical bleaching: experiments with loess fine grains. Quaternary Science Reviews 13(5-7): 457-463, DOI 10.1016/0277-3791(94)90058-2. 